\title{
Effects of age, photoperiod and follicle-stimulating hormone on lactate production by cultured Sertoli cells from prepubertal Siberian hamsters (Phodopus sungorus)
}

\author{
S. C. Newton ${ }^{1 *}$, M. J. Welsh ${ }^{2}$ and A. Bartke ${ }^{1}$ \\ ${ }^{1}$ Southern Illinois University, School of Medicine, Department of Physiology, Carbondale, \\ IL 62901-6512, USA; and ${ }^{2}$ Department of Anatomy and Cell Biology, University of Michigan, \\ School of Medicine, Ann Arbor, MI 48109, USA
}

\begin{abstract}
Summary. To define a functional difference in Sertoli cells of animals exposed to different photoperiodic conditions, we isolated Sertoli cells from the testes of juvenile Siberian hamsters and cultured them in serum-free medium. In all age groups studied, Sertoli cells isolated from hamsters with delayed and normal puberty responded to folliclestimulating hormone (FSH) with an increase in lactate production. The increase in lactate production induced by $1000 \mathrm{ng} \mathrm{FSH} \mathrm{ml}^{-1}$ was significantly greater in Sertoli cells isolated from hamsters with delayed puberty than in those with normal puberty. These results suggest that Sertoli cells of Siberian hamsters exposed to short photoperiod in vivo may respond to increases in plasma FSH concentrations associated with photostimulation or spontaneous sexual maturation by an increase in secretory activity that may be critical for the initiation of spermatogenesis.
\end{abstract}

Keywords: Sertoli cells; Siberian hamster; photoperiodism; follicle-stimulating hormone; lactate

\section{Introduction}

The Siberian hamster (Phodopus sungorus) is a seasonally breeding rodent, which breeds in the spring and summer in its natural habitat and in photoperiods of $14 \mathrm{~h}$ under laboratory conditions (Hoffmann, 1973). A short photoperiod $\left(<10 \mathrm{~h} \mathrm{light} \mathrm{day}^{-1}\right.$ ) causes a delay of several months in sexual maturation (Hoffmann, 1978). Such a delay in puberty resembles the situation described in some other rodent species (Horton, 1984), but differs from the effects of ambient photoperiod on reproductive function in the golden hamster (Darrow et al., 1980). We studied the effects of short and long photoperiods on testicular development in Siberian hamsters to identify functional changes in the Sertoli cells that are related to the onset of spermatogenesis. This experimental model allows separation of the changes related to chronological age from those related to pubertal development.

Sertoli cells are important mediators of the effects of hormones, toxicants, temperature and other factors on spermatogenesis (Steinberger, 1971). Of the numerous products of the Sertoli cell, lactic acid has been proposed as a possible mediator of the effects of follicle-stimulating hormone (FSH) on spermatogenesis (Robinson \& Fritz, 1981; Mita \& Hall, 1982; Mita et al., 1982). In rats, lactate was reported to be the preferred energy substrate for developing germ cells in vitro (Jutte et al., 1981) and was shown to increase oxygen consumption (Jutte et al., 1981), incorporation of $\left[{ }^{3} \mathrm{H}\right]$ uridine (Jutte et al., 1982) and $\left[{ }^{3} \mathrm{H}\right]$ leucine (Jutte et al., 1983) and ATP production (Grootegoed et al., 1984) in germ-cell cultures. The key role of FSH in the control of pubertal development in

*Present address: University of South Carolina, School of Medicine, Department of Cell Biology and Neurosciences, Columbia, SC 29208, USA. 
Siberian hamsters is supported by the changes in plasma FSH concentrations during maturation (Yellon \& Goldman, 1984) and by the demonstration that suppressing the normal increase in plasma FSH in photostimulated hamsters by injections of porcine follicular fluid delayed testicular growth (Milette et al., 1988). Follicle-stimulating hormone alone or in combination with luteinizing hormone $(\mathrm{LH})$ causes an increase in testicular weight, restoration of seminiferous tubule diameter and complete restoration of spermatogenesis in testicularly regressed adult Siberian hamsters (Niklowitz \& Hoffmann, 1989).

In adult Syrian hamsters (Mesocricetus auratus), the number of testicular FSH receptors and the responsiveness of Sertoli cells to FSH in vitro are influenced by photoperiod exposure in vivo. Thus, exposure to short photoperiods results in an increased concentration, but a reduced total number of testicular FSH receptors (Klemcke et al., 1987; Sinha-Hikim et al., 1989). Furthermore, Sertoli cells isolated from testicularly regressed Syrian hamsters respond to FSH with a greater increase in cAMP synthesis than do cells isolated from testicularly active animals (Heindel et al., 1981; Berkowitz \& Heindel, 1984; Heindel, 1988). In the present study, Sertoli cells were isolated from Siberian hamsters aged 12-15, 18-21, 24-27 or 30-33 days, born and raised in a long or a short photoperiod, and were maintained in culture. These cultures were used to examine the effects of age and photoperiod on the ability of Sertoli cells to produce lactate and to respond to FSH in vitro.

\section{Materials and Methods}

\section{Animals}

Siberian hamsters were obtained from a breeding colony originating from animals kindly provided by $B$. Goldman (University of Connecticut, Storrs, CT, USA) and maintained at Southern Illinois University in Carbondale, USA. Tekland laboratory chow and water were provided ad libitum. Short (S) photoperiods provided $6 \mathrm{~h}$ of light day ${ }^{-1}$ and long (L) photoperiods provided $16 \mathrm{~h}$ of light $\mathrm{day}^{-1}$. All reagents were obtained from Sigma Chemical Company, St Louis, MO, USA, unless otherwise indicated.

\section{Isolation and culture of Sertoli cells}

Enriched populations of Sertoli cells were prepared by a modification of the procedure of Welsh \& Wiebe (1975), as described by Ireland \& Welsh (1987). The testes were aseptically removed, decapsulated and placed in a solution of phosphate-buffered saline lacking calcium and magnesium (solution A) and subjected to sequential digestions with collagenase (2-4 mg per $20 \mathrm{ml}$ solution) and pancreatin ( $2 \mathrm{mg}$ enzyme per $20 \mathrm{ml}$ solution). In animals exposed to short photoperiods, the tubules were washed with the aid of low-speed $(60 \mathrm{~g})$ centrifugation in $15 \mathrm{ml}$ sterile polystyrene centrifuge tubes (Baxter Scientific products, McGraw Park, IL, USA) because the tubules were small. The resulting cell clusters were resuspended in a 1:1 mixture of Dulbecco's modified Eagle's medium and Ham's F-12 medium, supplemented with growth factors (final concentrations in media were $10 \mu \mathrm{g}$ insulin ml $\mathrm{m}^{-1}, 5 \mu \mathrm{g}$ transferrin ml $\mathrm{m}^{-1}$, and $0.25 \mathrm{ng}$ epidermal growth factor $\mathrm{ml}^{-1}$ ) and antibiotics (final concentrations in media were $2 \mathrm{U}$ penicillin ml $\mathrm{ml}^{-1}, 2 \mu \mathrm{g}$ streptomycin $\mathrm{ml}^{-1}, 1 \mu \mathrm{g}$ gentamicin $\mathrm{ml}^{-1}$ and 5.0 $\mathrm{ng}$ amphotericin B ml${ }^{-1}$; Mather et al., 1983; Newton et al., 1989). This was similar to the 3F medium of Rich et al. (1983) and Wright et al. (1989), which was considered a serum-free basal medium. Insulin in high concentrations increased the secretion of androgen-binding protein and lactate (Rich $e t$ al., 1983; Oonk et al., 1985), while the effects of transferrin and epidermal growth factors were less defined (Rich $e t$ al., 1983). Cells were cultured on $35 \mathrm{~mm}$ diameter culture dishes (Falcon plastics), at $34^{\circ} \mathrm{C}$ in an atmosphere of $95 \%$ air and $5 \%$ carbon dioxide. Approximately two plates per animal were obtained from S animals and from 12-15-day-old $\mathrm{L}$ animals and three plates per animal from the older $\mathrm{L}$ hamsters. The media were changed daily, each dish containing $2 \mathrm{ml}$ of medium. The cells were allowed 4 days to attain confluency and the experiments were performed on the fifth day after isolation.

\section{Assays}

Experiments ran for $8 \mathrm{~h}$, because this was determined to be the optimal duration for measurements of lactate production by isolated rat Sertoli cells (Oonk et al., 1985). After that, the media were collected for lactate determinations (Gutmann \& Wahlefeld, 1974). An aliquot of each of the samples was de-proteinized with perchloric acid $\left(1 \mathrm{moll}^{-1}\right)$. This acid solution was centrifuged and the supernatant was assayed for lactate using lactate dehydrogenase (Sigma catalog number 826-6). In this procedure, the amount of reduced nicotinamide adenosine dinucleotide (NADH), measured as absorbance at $340 \mathrm{~nm}$ formed from NAD (Sigma N7004), provides a measure of the original lactate 
concentration in the sample. Monolayers of Sertoli cells were incubated for, at most, $24 \mathrm{~h}$ at $34^{\circ} \mathrm{C}$ with $1 \mathrm{ml}$ of $\mathrm{NaOH}$ solution $\left(0.3 \mathrm{moll}^{-1}\right)$, which caused the cells to lyse so that DNA and protein could be determined (Giles \& Myers, 1965; Bradford, 1976; Patterson, 1979).

Cell viability was determined by trypan blue exclusion, and $>95 \%$ of the cultured cells were viable. Occasionally, to check for possible contamination with Leydig cells, Sertoli cell cultures were stained histochemically for $3 \beta$ hydroxysteroid dehydrogenase as described by Welsh \& Wiebe (1975) and were virtually negative for the presence of this enzyme. Possible contamination of Sertoli cell monolayers by peritubular (myoid) cells was evaluated by use of alkaline phosphatase histochemistry according to the procedure of Chapin et al. (1987). According to a report by Palombi \& Di Carlo (1988), alkaline phosphatase histochemistry selectively detects desmin-containing contractile cells in cultures of tubular and peritubular cells (see also Anthony \& Skinner, 1989). Sertoli cell monolayers isolated in this study were $>95 \%$ free of contamination with peritubular myoid cells, possibly because of the isolation technique and the use of serum-free media. It is generally accepted that peritubular cells do not contain FSH receptors (Orth \& Christensen, 1977) and therefore do not respond to FSH stimulation. However, paracrine regulation cannot be ruled out and therefore peritubular (myoid) cell contamination was kept to a minimum. Contamination with spermatogenic cells was generally $<5 \%$ after five changes of medium. Cultures from $\mathrm{L}$ animals generally contained more spermatogenic cells than those from $\mathrm{S}$ animals.

The effects of FSH on lactate production were examined using 125, 250, 500, 1000, 2000 and $5000 \mathrm{ng}$ ovine FSH (oFSH-S17, kindly provided by NIH) $\mathrm{ml}^{-1}$ of culture medium. The data were expressed as percentage of a mean basal lactate value determined within each experiment to correct for the effects of cell density on Sertoli cell function and intra-isolation variability.

\section{Statistical analysis}

Data were analysed by ANOVA, appropriate to the design, and a Student Neuman-Keuls test at the $95 \%$ confidence limit was used to determine which treatment group means were significantly different. Student's $t$ tests were performed when only two groups were compared. Pearson's correlation coefficient and probability were determined to identify responses that were dose related. The statistics were analysed with the aid of the Crisp statistical package for personal computers (Crunch Software Corp., San Francisco, CA, USA).

\section{Results}

Sertoli cells isolated from hamsters exposed to long or short photoperiods responded to oFSH with a characteristic shape change (Fig. 1) and by a significant increase in the accumulation of lactate in the incubation medium. Under basal conditions, Sertoli cells from $\mathrm{S}$ hamsters produced significantly more lactate than those from $L$ animals $\left(101.1 \pm 11.9\right.$ versus $39.97 \pm 4.59 \mu \mathrm{g} \mathrm{g}^{-1}$ DNA in $8 \mathrm{~h} ; P<0.001)$. The response of Sertoli cells derived from S 18-21-day-old hamsters to oFSH was dose dependent over the whole range of oFSH concentrations used in this study $\left(125-5000 \mathrm{mg} \mathrm{ml}^{-1}\right.$ ) with a correlation of 0.70 and a slope of $0.025 \mu \mathrm{g}$ lactate $\mu \mathrm{g}^{-1}$ DNA as a percentage of basal $\mathrm{ng}^{-1}$ oFSH $(P<0.00001)$. The median effective dose of oFSH for lactate production was $500 \mathrm{ng} \mathrm{ml}^{-1}$ (Fig. 2b).

Lactate production by Sertoli cells isolated from $\mathrm{L}$ exposed hamsters of the same age was dose dependent between 125 and $1000 \mathrm{ng} \mathrm{ml}^{-1}$ with a correlation of 0.63 and a slope of $0.039 \mu \mathrm{g}$ lactate $\mu \mathrm{g}^{-1}$ DNA as a percentage of basal $\mathrm{ng}^{-1} \mathrm{oFSH}(\mathrm{P}<0.00001)$ (Fig. 2b). In the presence of higher doses of oFSH, lactate production from $L$ Sertoli cells was not significantly different from basal values $(P>0.05)$. On the basis of these results, doses of 500 and $1000 \mathrm{ng} \mathrm{FSH} \mathrm{ml}^{-1}$ were selected for the study of the effects of photoperiod exposure in vivo on lactate production in vitro from Sertoli cells in other age groups.

\section{Lactate production by Sertoli cells}

From hamsters 12-15 days old. Lactate production from L Sertoli cells was significantly greater than basal concentrations in the presence of 500 or $1000 \mathrm{ng} \mathrm{oFSH} \mathrm{ml}^{-1}(P<0.05)$. Lactate values measured in the presence of $1000 \mathrm{ng}$ oFSH were significantly greater than in the presence of $500 \mathrm{ng}$ $\mathrm{ml}^{-1}(P<0.05)$. Lactate production in response to oFSH was dose related, with a correlation coefficient of 0.75 and a slope of $0.073 \mu \mathrm{g}$ lactate $\mu \mathrm{g}^{-1}$ DNA as a percentage of basal ng ${ }^{-1} \mathrm{oFSH}$. 

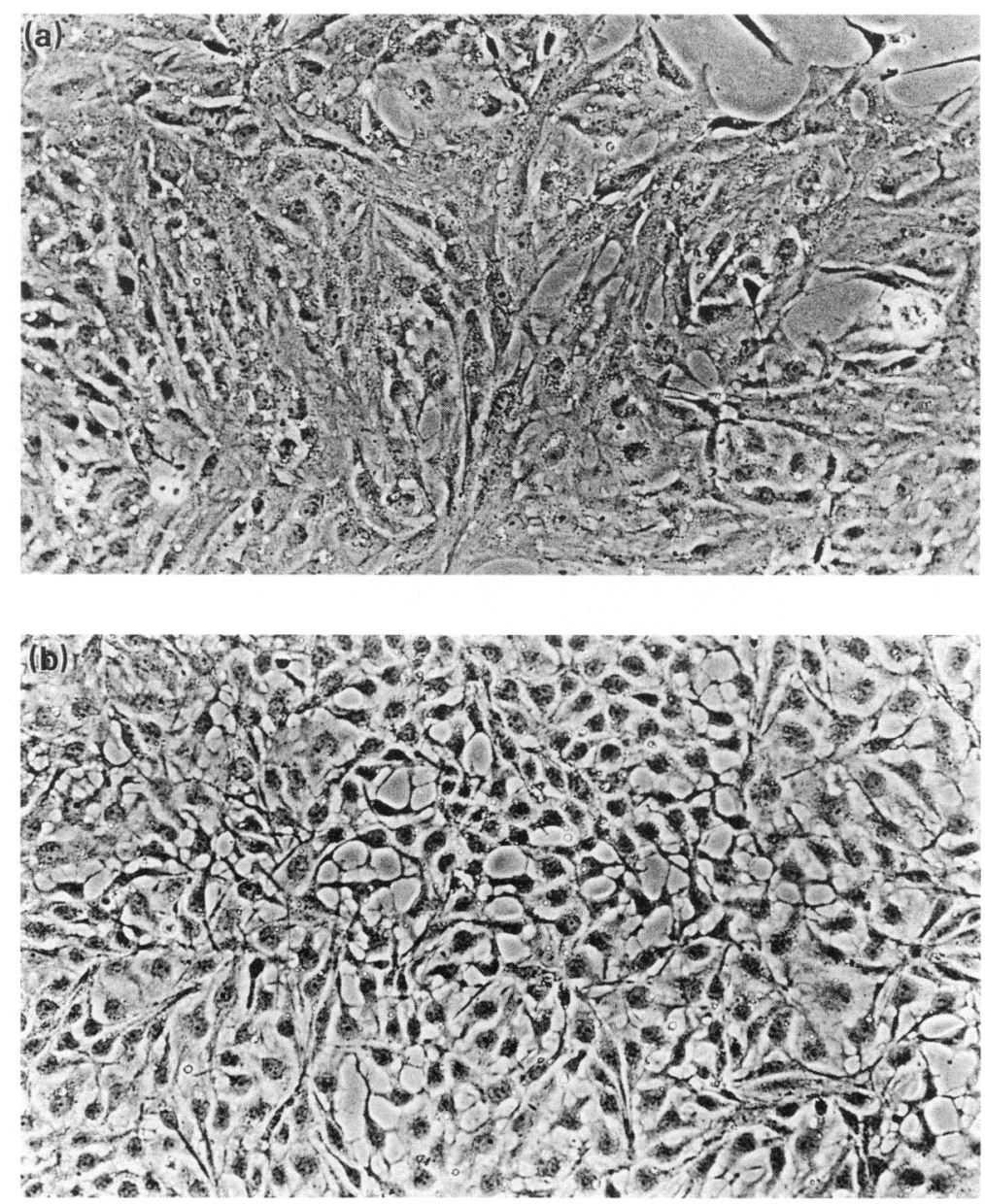

Fig. 1. Phase-contrast micrograph of Siberian hamster Sertoli cells in culture under (a) basal conditions and (b) the influence of stimulation by follicle-stimulating hormone ( $1 \mu \mathrm{g} \mathrm{oFSH}-\mathrm{S} 17$ $\mathrm{ml}^{-1}$ for $30 \mathrm{~min}$ ). Note the difference in the shape of the cells; $\times 160$.

In Sertoli cells, doses of 500 and $1000 \mathrm{ng} \mathrm{oFSH} \mathrm{ml}{ }^{-1}$ could also stimulate lactate production above basal rates, lactate production by Sertoli cells treated with $1000 \mathrm{ng} \mathrm{oFSH} \mathrm{ml}{ }^{-1}$ being significantly greater than the corresponding value for cells treated with $500 \mathrm{ng} \mathrm{oFSH} \mathrm{ml} l^{-1}(P<0.01)$. These responses were dose related, with a correlation coefficient of $0.91(P<0.00001)$ and a slope of $0.096 \mu \mathrm{g}$ lactate $\mu \mathrm{g}^{-1} \mathrm{DNA}$ as a percentage of basal $\mathrm{ng}^{-1} \mathrm{oFSH}$. Lactate production by S Sertoli cells treated with $1000 \mathrm{ng}$ oFSH ml ${ }^{-1}$ was significantly greater than in identically treated L Sertoli cells ( $t$ test; $P<0.05$; Fig. 2a).

From hamsters 24-27 days old. Both the doses of oFSH significantly stimulated lactate production by $\mathrm{L}$ Sertoli cells $(P<0.01)$. Lactate production in the presence of $1000 \mathrm{ng} \mathrm{oFSH} \mathrm{ml}^{-1}$ was not significantly different from the values measured at $500 \mathrm{ng} \mathrm{oFSH} \mathrm{ml}^{-1}(P>0.05)$. Nevertheless, the effect of oFSH on lactate production from L Sertoli cells was dose related, with a correlation coefficient of $0.62(P<0.0000 \mathrm{I})$ and slope of $0.054 \mu \mathrm{g}$ lactate $\mu \mathrm{g}^{-1}$ DNA as a percentage of basal $\mathrm{ng}^{-1} \mathrm{oFSH}$. Both 500 and $1000 \mathrm{ng}_{\mathrm{oFSH} \mathrm{ml}}^{-1}$ also stimulated lactate production from S Sertoli cells $(P<0 \cdot 01)$. Values obtained with $1000 \mathrm{ng} \mathrm{oFSH} \mathrm{ml}^{-1}$ were significantly greater than in the presence of $500 \mathrm{ng} \mathrm{FSH} \mathrm{ml}^{-1}(P<0.05)$. The effect of FSH on lactate production by Sertoli cells was dose related, with a correlation coefficient of 0.85 and slope of $0.087 \mu \mathrm{g}$ lactate $\mu \mathrm{g}^{-1} \mathrm{DNA}$ as a 

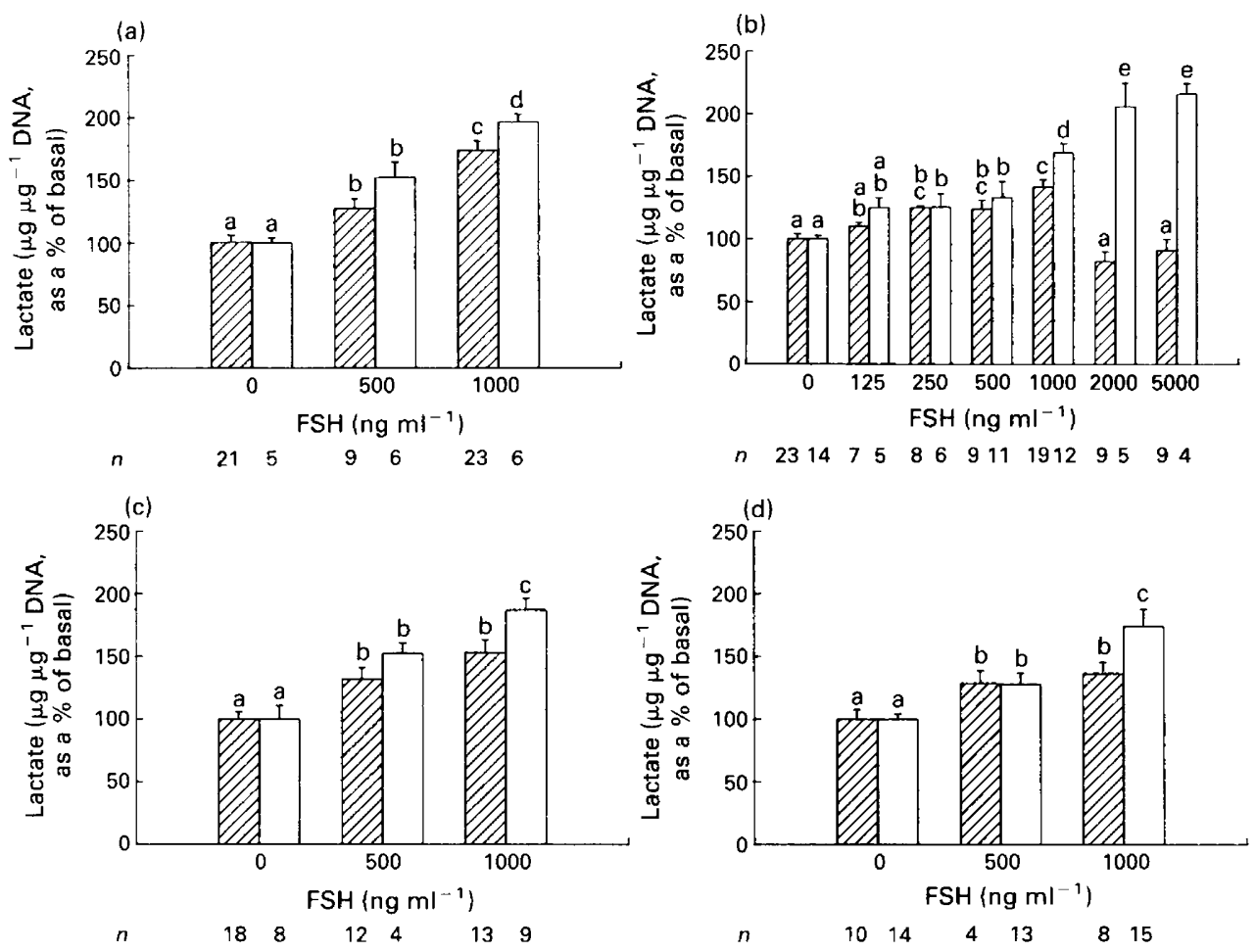

Fig. 2. Effects of various doses of follicle-stimulating hormone (FSH) on lactate secretion from Sertoli cells isolated from Siberian hamsters reared in long ( $\mathrm{Q}$ ) or short ( $\square$ ) photoperiods (a) 12-15 (b) 18-21 (c) 24-27 or (d) 30-33 days old at the time of culture. Lactate secretion (mean \pm SEM) is expressed as $\mu \mathrm{g}$ lactate $\mu \mathrm{g}^{-1}$ DNA as a percentage of basal, after incubation for $8 \overline{\mathrm{h}}$. Different letters indicate significant differences $(P<0.05)$ between treatment groups. Numbers under the columns indicate number of plates per treatment group.

percentage of basal $\mathrm{ng}^{-1} \mathrm{oFSH}$. Lactate production by S Sertoli cells treated with $1000 \mathrm{ng}$ oFSH $\mathrm{ml}^{-1}$ was significantly greater than by identically treated L Sertoli cells ( $t$ test; $P<0 \cdot 03$; Fig. $2 \mathrm{c}$ ).

From hamsters 30-33 days old. Lactate production from L Sertoli cells was greater than basal levels with either of the doses of oFSH. Values obtained from L Sertoli cells treated with $1000 \mathrm{ng}$ oFSH ml ${ }^{-1}$ were not significantly different from values measured at $500 \mathrm{ng} \mathrm{oFSH} \mathrm{ml}^{-1}(P>0 \cdot 05)$, but the results were dose related, with a correlation coefficient of 0.62 and a slope of $0.037 \mu \mathrm{g}$ lactate $\mu \mathrm{g}^{-1}$ DNA as a percentage of basal $\mathrm{ng}^{-1} \mathrm{FSH}$. The production of lactate by S Sertoli cells was also greater than basal with either 500 or $1000 \mathrm{ng} \mathrm{oFSH} \mathrm{ml}^{-1}$, the effect of the higher dose being significantly greater $(P<0.05)$. Lactate production by $\mathrm{S}$ Sertoli cells was dose related, with a correlation coefficient of $0.66(P<0.0001)$ and a slope of $0.074 \mu \mathrm{g}$ lactate $\mu \mathrm{g}^{-1} \mathrm{DNA}$ as a percentage of basal $\mathrm{ng}^{-1} \mathrm{oFSH}$. Lactate production by S Sertoli cells treated with $1000 \mathrm{ng} \mathrm{oFSH} \mathrm{ml}^{-1}$ was significantly greater than by identically treated $L$ Sertoli cells ( $t$ test; $P<0.03$; Fig. 2 d).

\section{Discussion}

Cultures of Sertoli cells isolated from immature Siberian hamsters were viable and virtually free of other testicular cell types. When treated with FSH, the cultured cells exhibited a clear morphological response (shape change); in rat Sertoli cells such a change accompanies an increase in intracellular cyclic AMP (Kierszenbaum et al., 1985). 
Lactate production by Sertoli cells from L and S hamsters 18-21 days old were stimulated with ovine FSH (125-1000 $\mathrm{ng} \mathrm{ml}^{-1}$ ) in a dose-related manner. Although lactate may not be the sole regulator of spermatogenesis, it is an indicator of Sertoli cell function. Radioimmunoassay using commercially available rat transferrin (Cappel Laboratories, West Chester, PA, USA) failed to detect Siberian hamster transferrin in serum and Sertoli cell medium (S. C. Newton \& A. Bartke, unpublished data). Results presented here resemble those obtained by Jutte et al. (1983) in cultures of rat Sertoli cells. The high dose of FSH needed to stimulate secretion of lactate may be due to species differences in responsiveness to FSH. High doses of FSH (2000 and $\left.5000 \mathrm{ng} \mathrm{ml}^{-1}\right)$ stimulated lactate production in S Sertoli cells, but not in L Sertoli cells, indicating that Sertoli cells isolated from $L$ hamsters may be more susceptible to desensitization at higher doses of FSH. In another seasonal breeder, the adult golden (Syrian) hamster, injections with human chorionic gonadotrophin (hCG) produced a dose-dependent decrease in the number of testicular LH receptors in gonadally active animals (Amador et al., 1985). In contrast, testes from testicularly regressed golden hamsters showed an increase in testicular $\mathrm{LH}$ and hCG receptors after injections of hCG (with the exception of a high dose, $0.9 \mathrm{i} . \mathrm{u} . \mathrm{hCG} \mathrm{g}^{-1}$ body weight), thus resembling the responses measured in immature animals (Amador et al., 1985). Testicularly regressed golden hamsters could also respond to a second challenge of hCG, $24 \mathrm{~h}$ after a priming dose, with increased serum testosterone concentrations (Amador et al., 1985).

Regulation of FSH receptors by FSH has been demonstrated in several species (Orth \& Christensen, 1977; Thanki \& Steinberger, 1978; Tsutsui \& Ishii, 1978; Salhanick \& Wiebe, 1980; Klemcke et al., 1987). No data are available on the effects of photoperiod or puberty on testicular FSH binding in Siberian hamsters. However, it is possible that the increased sensitivity of Sertoli cells from S hamsters to FSH reflects either upregulation of FSH receptors in response to suppression of endogenous FSH release (Yellon \& Goldman, 1984) or the ability of FSH to increase, rather than deplete, the number of FSH-binding sites in $\mathrm{S}$ animals.

Berkowitz \& Heindel (1987) reported that the inhibin-like activity of conditioned media of golden hamster Sertoli cells was greatest from cells isolated from $\mathrm{S}$ hamsters. Moreover, the pituitaries from $\mathrm{S}$ hamsters were more sensitive to the action of inhibin. The result is a decrease in FSH release from the anterior pituitary and possible upregulation of the FSH receptors on Sertoli cells.

Testes from adult $L$ Siberian hamsters exhibit full spermatogenesis, with paired testes of approximately $400 \mathrm{mg}$, while S animals produce no advanced germ cells, with paired testes of approximately $15 \mathrm{mg}$ (Hoffmann, 1978). The presence or absence of germ cells has been reported to influence the function of Sertoli cells, including a decrease in RNA synthesis in Sertoli cells (Rivarola et al., 1986), decreased secretion of androgen-binding protein (ABP) in response to FSH or dbcAMP when germ cells are added to Sertoli cells in vitro (Le Magueresse \& Jegou, 1988; Le Magueresse et al., 1988), appearance of a $48 \mathrm{kDa}$ glycoprotein in rat Sertoli cell cultures in the absence of germ cells (Galdeiri et al., 1984). Some proteins that may be important in spermatogenesis, such as plasminogen activator, are secreted at a particular stage of spermatogenesis (Fritz \& Karmally, 1983; Vihko et al., 1984; Shabanowitz et al., 1986; Wright \& Luzzaraga, 1986), suggesting that germ cells affect Sertoli cell function. Germ-cell-dependent changes in phosphorylation of Sertoli cell proteins have been demonstrated (Ireland \& Welsh, 1987) and, on this basis, a signal transduction mechanism by which germ cells may affect Sertoli cell function has been suggested to be the phosphatidylinositol pathway (Ireland \& Welsh, 1987; M. J. Welsh \& M. E. Ireland, unpublished). Testes from prepubertal animals (S) have a lower complement of spermatogenic cells in vivo and therefore are not subjected to the possible paracrine regulation of Sertoli cell function by spermatogenic cells compared with testes from $L$ animals. This is also apparent after cell isolation, since L Sertoli cells have more contaminating spermatogenic cells. It is possible that L Sertoli cells have the receptors for these paracrine regulators, while S Sertoli cells have less-developed receptors.

Sertoli cells isolated from hypophysectomized or cryptorchid adult golden hamsters that had undergone testicular regression could respond to FSH with an accumulation of cAMP similar to that in Sertoli cells isolated from immature hamsters or adult hamsters exposed to short 
photoperiod (Heindel, 1990). This response was specific for FSH in that cholera toxin, forskolin or isoproterenol caused a response similar to that in $\mathrm{L}$ adults. Cryptorchidism causes a decrease in testicular weight (regression) due to damage to advanced germ cells (Aumuller, 1980). Hypophysectomy causes regression by removing the source of gonadotrophins. In either case, a lack of advanced germ cells is observed, and responsiveness of cultured Sertoli cells to the actions of FSH is increased. This strongly suggests an action of germ cells, possibly paracrine, on Sertoli cell responsiveness to FSH (Heindel, 1990). Indeed, pretreatment of Sertoli cells with germ cells has been observed to reduce, by about $50 \%$, the subsequent response to FSH as measured by cAMP production from ATP by Sertoli cell membrane fractions (M. J. Welsh \& M. E. Ireland, unpublished).

The stimulatory effect of FSH on lactate production by Sertoli cells isolated from animals of all age groups studied was dose related. However, at all ages examined, the correlation coefficient and the slope were numerically greater in S Sertoli cell cultures than in L Sertoli cell cultures. In Sertoli cells from L animals, 18-21 days old or older, production of lactate in response to 500 or $1000 \mathrm{ng}$ oFSH $\mathrm{ml}^{-1}$ was not significantly different. This implies a shift in the dose-response curve with a plateau beginning near $500 \mathrm{ng}$ FSH ml$~^{-1}$. In other words, lactate production in response to $1000 \mathrm{ng} \mathrm{ml}^{-1}$ in $\mathrm{L}$ Sertoli cells appears to decrease with age of the hamsters, as was reported for cultured Sertoli cells in rats (Rich et al., 1983) and golden hamsters (Berkowitz \& Heindel, 1987). Lactate production from S Sertoli cells treated with $1000 \mathrm{ng}$ oFSH ml ${ }^{-1}$ was greater than from identically treated $\mathrm{L}$ cells in all age groups examined.

The responsiveness of Sertoli cells to FSH varies with the age of the animal. In rats, response to both basal adenylate cyclase and FSH stimulation of adenylate cyclase declines between the ages of 12 and 60 days (Van Sickle et al., 1981). The binding of FSH to Sertoli cells increases up to 16 days of age and then declines to adult levels (Thanki \& Steinberger, 1978; Salhanick \& Wiebe, 1980). This age-related loss of Sertoli cell responsiveness to FSH was observed in the present study in $\mathrm{L}$ Siberian hamsters, but not in $\mathrm{S}$ animals. It can be concluded that Sertoli cells from immature Siberian hamsters are well prepared to respond to FSH when FSH is increased during the process of photostimulation or spontaneous sexual development. Our results demonstrate that Sertoli cells from $L$ hamsters undergo a gradual decrease in responsiveness to FSH with age, while those from $\mathrm{S}$ animals maintain a prepubertal condition with a greater response to FSH than is observed in age-matched animals raised in long photoperiods. Whether these differing responses are due to desensitization of the FSH response or to the residual influence of advanced germ cells on Sertoli cell function remains to be determined.

This research was supported by NIH through grant HD20033. We thank S. Raiti of the National Hormone and Pituitary program for FSH.

\section{References}

Amador, A., Bartke, A., Klemcke, H.G., Siler-Khodr, T.M. \& Stallings, M.H. (1985) Effects of photoperiod and $\mathrm{hCG}$ on the regulation of testicular $\mathrm{LH} / \mathrm{hCG}$ receptors in Syrian hamsters (Mesocricetus auratus). Journal of Reproduction and Fertility 74, 693-700.

Anthony, C.T. \& Skinner, M.K. (1989) Cytochemical and biochemical characterization of testicular peritubular myoid cells. Biology of Reproduction 40, 811-823.

Aumuller, G., Hartmann, K., Giers, U. \& Schenck, B. (1980) Fine structure of the Sertoli cells of the rat testes in experimental unilateral cryptorchidism. International Journal of Andrology 3, 301-311.

Berkowitz, A.S. \& Heindel, J.J. (1984) Testicular recrudescence in the golden hamster (Mesocricetus auratus) a possible model of sexual maturation. Endocrinology 114, 855-860.
Berkowitz, A.S. \& Heindel, J.J. (1987) Inhibin production by Sertoli cells during testicular regression in the golden hamster. Journal of Andrology 8, 195-205.

Bradford, M.M. (1976) A rapid and sensitive method for the quantitation of microgram quantities of protein utilizing the principle of protein-dye binding. Analytical Biochemistry 72, 248-254.

Chapin, H.J., Phelps, J.L., Miller, B.E. \& Gray, T.J.B. (1987) Alkaline phosphatase histochemistry discriminates peritubular cells in primary rat testicular cell culture. Journal of Andrology 8, 155-161.

Darrow, J.M., Davis, F.C., Elliott, J.A., Stetson, M.H., Turek, F.W. \& Menaker, M. (1980) Influence of photoperiod on reproductive development in the golden hamster. Biology of Reproduction 22, 443-450. 
Fritz, I.B. \& Karmally, K. (1983) Hormonal influence on formation of plasminogen activator by cultured testis tubule segments at defined stages of the cycle of the seminiferous epithelium. Canadian Journal of Biochemistry and Cell Biology 61, 553-560.

Galdieri, M., Monaco, L. \& Stefanini, M. (1984) Secretion of androgen binding protein by Sertoli cells is influenced by contact with germ cells. Journal of Andrology 5, 409-415.

Giles, K.W. \& Meyers, A. (1965) An improved diphenylamine method for the estimation of deoxyribonucleic acid. Nature 206, 93.

Grootegoed, J.A., Jansen, R. \& Van der Molen, H.J. (1984) The role of glucose, pyruvate and lactate in ATP production by rat spermatocytes and spermatids. Biochimica et Biophysica Acta 767, 248-256.

Gutmann, I. \& Wahlefeld, A. W. (1974) L-(+)-lactate determination with lactate dehydrogenase and NAD. In Methods of Enzymatic Analysis, Vol. 3, pp. 1464 1468. Ed. H. U. Bergmeyer. Verlag Chemie WeiheinAcademic Press, Inc, New York and Toronto.

Heindel, J.J. (1988) Age-related and testicular regressioninduced changes in adenosine $3^{\prime}, 5^{\prime}$-monophosphate responses in cultured hamster Sertoli cells. Endocrinology 122, 475-484.

Heindel, J.J. (1990) cAMP response of cultured Sertoli cells from immature and adult hamsters: effect of hypophysectomy and cryptorchidism. Journal of Andrology 11, 59-65.

Heindel, J.J., Berkowitz, A.S., Philo, R. \& Preslock, J.P. (1981) FSH stimulation of cAMP accumulation in hamster Sertoli cells: effect of age and optic enucleation. Journal of Andrology 2, 217-221.

Hoffmann, K. (1973) The influence of photoperiod and melatonin on testis size, body weight and pelage colour in the Djungarian hamster (Phodopus sungorus). Journal of Comparative Physiology 85, 267-282.

Hoffmann, K. (1978) Effects of short photoperiod on puberty and moult in the Djungarian hamster (Phodopus sungorus). Journal of Reproduction and Fertility 54, 29-35.

Horton, T.H. (1984) Growth and maturation in Microtus montanus: effects of photoperiods before and after weaning. Canadian Journal of Zoology 62, 1741-1746.

Ireland, M.E. \& Welsh, M.J. (1987) Germ cell stimulation of Sertoli cell protein phosphorylation. Endocrinology 120, $1317-1325$.

Jutte, N.H.P.M., Grootegoed, J.A., Rommerts, F.F.G. \& Van der Molen, H.J. (1981) Exogenous lactate is essential for metabolic activities in isolated rat spermatocytes and spermatids. Journal of Reproduction and Fertility 62, 399-405.

Jutte, N.H.P.M., Jansen, R., Grootegoed, J.A., Rommerts, F.F.G., Clausen, O.P.F. \& Van der Molen, H.J. (1982) Regulation of survival of rat pachytene spermatocytes by lactate supply from Sertoli cells. Journal of Reproduction and Fertility 65, 431-438.

Jutte, N.H.P.M., Jansen, R., Grootegoed, J.A., Rommerts, F.F.G. \& Van der Molen, H.J. (1983) FSH stimulation of the production of pyruvate and lactate by rat Sertoli cells may be involved in hormonal regulation of spermatogenesis. Journal of Reproduction and Fertility 68, 219-226.

Kierszenbaum, A.L., Spruil, W.A. \& White, M.G. (1985) Rat Sertoli cells acquire a $\beta$-adrenergic response during primary culture. Proceeding of the National Academy of Science USA 82, 2049-2053.

Klemcke, H.G., Van Sickle, M., Bartke, A., Amador, A.G. \& Chandrashekar, V. (1987) Effects of photoperiod, hypophysectomy and follicle-stimulating hormone on testicular follicle-stimulating binding in golden hamsters. Biology of Reproduction 37, 356-370.

Le Magueresse, B. \& Jegou, B. (1988) In vitro effects of germ cells on the secretory activity of Sertoli cells recovered from rats at different ages. Endocrinology 122, 1672-1680.

Le Magueresse, B., Pineau, C., Guillou, F. \& Jegou, B. (1988) Influence of germ cells upon transferrin secretion by rat Sertoli cells in vitro. Journal of Endocrinology 118, R13-R16.

Mather, J.P., Zhuang, I-Z., Perez-Infante, V. \& Philips, D.M. (1983) Culture of testicular cells in hormonesupplemented serum-free medium. Annals of New York Academy of Sciences 383, $44-68$.

Milette, J.J., Schwartz, N.B. \& Turek, F.W. (1988) The importance of follicle-stimulating hormone in the initiation of testicular growth in photostimulated Djungarian hamsters. Endocrinology 122, 1060-1066.

Mita, M. \& Hall, P.F. (1982) Metabolism of round spermatids from rats: lactate as the preferred substrate Biology of Reproduction 26, 445-455.

Mita, M., Price, J.M. \& Hall, P.F. (1982) Stimulation by follicle-stimulating hormone of synthesis of lactate by Sertoli cells from rat testis. Endocrinology 110, 1535-1541.

Newton, S.C. (1989) Lactate secretion by Sertoli cells isolated from Djungarian hamsters exposed to different photoperiods. Biology of Reproduction Supplement, Abstract 186.

Newton, S.C., Bartke, A. \& Mayerhofer, A. (1989) Dopamine and isoproterenol stimulate lactate secretion from Sertoli cell cultures isolated from immature golden hamsters. Neuroendocrinology Letters 11, 207-214.

Niklowitz, P. \& Hoffmann, K. (1989) Differential effects of follicle-stimulating hormone and luteinizing hormone on Leydig cell function and restoration of spermatogenesis in hypophysectomized and photo-inhibited Djungarian hamsters (Phodopus sungorus). Biology of Reproduction 41, 871-880.

Oonk, R.B., Grootegoed, J.A. \& Van der Molen, H.J. (1985) Comparison of the effects of insulin and follitropin on glucose metabolism by Sertoli cells from immature rats. Molecular and Cellular Endocrinology 42, 39-48.

Orth, J. \& Christensen, A.K. (1977) Localization of ${ }^{125} \mathrm{I}$ labeled FSH in the testes of hypophysectomized rats autoradiography at the light and electron microscope levels. Endocrinology 101, 262-278.

Palombi, F. \& Di Carlo, C. (1988) Alkaline phosphatase is a marker for myoid cells in cultures of rat peritubular and tubular tissue. Biology of Reproduction 39, $1101-1109$.

Patterson, M.K. (1979) Measurement of growth and viability of cells in culture. Methods of Enzymology 58, $141-149$.

Rich, K.A., Bardin, C.W., Gunsalus, G.L. \& Mather, J.P. (1983) Age-dependent pattern of androgen binding protein secretion from rat Sertoli cells in primary culture. Endocrinology 113, 2284-2293. 
Rivarola, M.A., Sanchez, P. \& Saez, J.M. (1986) Inhibition of RNA and DNA synthesis in Sertoli cells by co-culture with spermatogenic cells. International Journal of Andrology 9, 424 434 .

Robinson, R. \& Fritz, I.B. (1981) Metabolism of glucose by Sertoli cells in culture. Biology of Reproduction 24, 1023-1041.

Salhanick, A.I. \& Wiebe, J.P. (1980) FSH receptors in isolated Sertoli cells: changes in concentration of binding sites at the onset of sexual maturation. Life Sciences 26, 2281-2288.

Shabanowitz, R.B., DePhilip, R.M., Crowell, J.A., Tres, L.L. \& Kierszenbaum, A.L. (1986) Temporal appearance of cyclic behavior of Sertoli cell-specific secretory proteins during the development of the rat seminiferous tubule. Biology of Reproduction 35, 745-760.

Sinha-Hikim, A.P., Amador, A.G., Klemcke, H.G., Bartke, A. \& Russell, L.D. (1989) Correlative morphology and endocrinology of Sertoli cells in hamster testes in active and inactive states of spermatogenesis. Endocrinology 125, 1829-1843.

Steinberger, E. (1971) Hormonal control of mammalian spermatogenesis. Physiological Reviews 51, 1-25.

Thanki, K.H. \& Steinberger, A. (1978) Effect of age and hypophysectomy on FSH binding by rat testis. Andrologia 10, 195-202.

Tsutzui, K. \& Ishii, S. (1978) Effect of follicle-stimulating hormone and testosterone on receptors of follicle- stimulating hormone in the testis of the immature Japanese quail. General and Comparative Endocrinology 36, 299-305.

Van Sickle, M., Oberwetter, J.M., Birnbaumer, L. \& Means, A.R. (1981) Development changes in the hormonal regulation of rat testis Sertoli cell adenylyl cyclase. Endocrinology 109, 1270-1279.

Vihko, K.K., Suominen, J.J.O. \& Parvinen, M. (1984) Cellular regulation of plasminogen activator secretion during spermatogenesis. Biology of Reproduction 31, 383-389.

Welsh, M.J. \& Wiebe, J.P. (1975) Sertoli cells: a rapid method for obtaining viable cells. Endocrinology 96, 618-624.

Wright, W.W. \& Luzzarga, M.L. (1986) Isolation of cyclic protein-2 from rat seminiferous tubule fluid and Sertoli cell culture medium. Biology of Reproduction 35, 761-772.

Wright, W.W., Zabludofi, S.D., Erickson-Lawrence, M. \& Karzai, A.W. (1989) Germ cell-Sertoli cell interaction: studies of cyclic protein-2 in the seminiferous tubule. Annals of New York Academy of Science 564, 173-185.

Yellon, S.M. \& Goldman, B.D. (1984) Photoperiodic control of reproductive development in the male Djungarian hamster (Phodopus sungorus). Endocrinology 114, 664-670.

Received 29 January 1991 